\title{
Promotion of flower opening in cut rose cultivars by 1-naphthaleneacetic acid treatment
}

\author{
Takanori Horibe $^{1 *}$ (D), Maho Makita ${ }^{1}$ (1) \\ ${ }^{1}$ Chubu University, College of Bioscience and Biotechnology, Kasugai, Japan.
}

\begin{abstract}
Improving the quality and rate of opening of cut flowers is important to meet consumer demand. Thus, it is important to develop methods to control the rate of flower opening and senescence in ornamental plants. In this study, we investigated the effects of 1-naphthaleneacetic acid (NAA) in flower opening in rose (Rosa sp.) cultivars Princess Meg, Red Star and Madrid. Cut roses were maintained under different concentrations of NAA. Shoot bases were immersed in water solution containing 0,100 , and 1,000 $\mu \mathrm{M}$ NAA, in addition to $2 \% \mathrm{w} / \mathrm{v}$ sucrose with $0.02 \% \mathrm{w} / \mathrm{v} 8$-hydroxyquinoline monohydrate. Subsequently, their vase life, flower opening, flower diameter and petal weight were measured. Flower opening in all three cultivars was clearly promoted by the $1,000 \mu \mathrm{M}$ NAA treatment, resulting in higher petal fresh weight and flower diameter at 2 days following treatment. $100 \mu \mathrm{M}$ NAA treatment also promoted flower opening and petal wilting in three cultivars, although the decrease in relative fresh weight of cut rose became slower and vase-life became longer than 1,000 $\mu \mathrm{M}$ NAA treatment in "Madrid". This indicates that NAA promotes flower opening and petal growth in three cut rose cultivars. However, NAA treatment also promoted petal wilting, resulting in shorter vase-life. Although rose cultivars differed in their sensitivity to the NAA treatment, we conclude that NAA shows high potential as a chemical agent for controlling flower opening in cut rose cultivars.
\end{abstract}

Keywords: Rosa spp.; cut flower quality; plant growth regulator; postharvest.

\section{Resumo}

Indução de abertura floral em cultivares de rosa por tratamento com ácido 1-naftalenoacético

É importante aperfeiçoar a qualidade e a taxa de abertura em flores de corte, conforme demanda dos consumidores. Portanto, o desenvolvimento de métodos que possam controlar tais processos é também importante. Neste estudo, foram investigados os efeitos do ácido 1-naftalenoacético (NAA) na abertura floral dos cultivares de rosas (Rosa sp.) Princess Meg, Red Star e Madrid. Rosas cortadas foram mantidas em diferentes concentrações de NAA. A base das hastes foi mantida em soluções aquosas contendo 0,100 e $1.000 \mu \mathrm{M}$ NAA, suplementadas com $2 \% \mathrm{p} / \mathrm{v}$ de sacarose e $0,02 \% \mathrm{p} / \mathrm{v}$ de 8 -hidroxiquinolina monohidratada. Em seguida, foram avaliadas a vida de vaso, abertura e diâmetro floral, bem como o peso das pétalas. A abertura floral dos três cultivares avaliados foi estimulada quando exposta ao $1.000 \mu \mathrm{M}$ NAA, o que resultou em maior peso fresco das pétalas e maior diâmetro floral dois dias após o tratamento. O tratamento contendo $100 \mu \mathrm{M}$ NAA também promoveu a abertura floral e a murcha das pétalas nas três cultivares, porém, o decréscimo no parâmetro peso fresco foi menor e a vida de vaso foi superior no cultivar Madrid quando comparado ao tratamento $1.000 \mu \mathrm{M}$ NAA. Isso indica que o NAA promove a abertura floral e o crescimento das pétalas nesses três cultivares. Contudo, o tratamento com NAA também acelerou a murcha das pétalas, resultando em redução da vida de vaso. Ainda que os cultivares avaliados tenham diferido na sensitividade ao NAA, pode-se concluir que o NAA apresenta alto potencial como agente químico para controlar a abertura floral em cultivares de rosa de corte.

Palavras-chave: Rosa spp.; qualidade de flor de corte; regulador de crescimento; pós-colheita.

\section{Introduction}

Rose (Rosa sp.) is one of the most important ornamental plants grown as cut flowers and garden plants. For example, in Japan, the rose production amount in 2017 was about 17 billion USD, and the flower is the fourth amount among ornamental flowers, after chrysanthemum, lily and orchid, according to statistical data from the Ministry of Agriculture, Forestry and Fisheries (Ministry of Agriculture, Forestry and Fisheries, 2017). The value of ornamental plants,

*Corresponding author: t-horibe@isc.chubu.ac.jp 
especially those with flowers, such as roses, depends on the successful blooming of flower buds. Therefore, it is important to establish methods to control the rates of flower opening and senescence (Horibe and Yamada, 2017).

The use of auxins to improve vase life of cut flowers is reported in some studies. For example, 1-naphthaleneacetic acid (NAA) treatment has been shown to be effective in improving the postharvest life of cut Eustoma flowers (Shimizu-Yumoto and Ichimura, 2010). It has also been reported that a pulse treatment of red cestrum (Cestrum elegans Schltdl.) cut flowers with 2,4-dichlorophenoxyacetic acid (2,4-D) significantly reduced floret bud abscission, whereas NAA was ineffective (Abebie et al., 2020). In another study, Khandaker et al. (2017) showed that spraying the plant with $25 \mathrm{mg} / \mathrm{L}$ NAA enhanced the growth and development of the Mokara Chark Kuan orchid cut flower. Ke et al. (2018) reported that endogenous auxin level controls circadian flower opening and closure in Nymphaea colorata. Cut rose flowers also show rhythmic flower opening, starting shortly before the light period and lasting a few hours (Horibe and Yamada, 2014). Therefore, we hypothesized that synthetic auxin can be used to control the rate of flower opening. However, it has been shown that ethylene sensitivities of cultivars or varieties can differ greatly even within a single species, as is the case with rose (Rosa sp.) and peony (Paeonia suffruticosa) (Ma et al., 2018). For example, Wu et al. (2017) studied the effect of ethylene and ethylene antagonist 1-methycyclopropene (1-MCP) on postharvest development of Paeonia suffruticosa using two cultivars. According to their study, postharvest development of the Luoyang Hong cultivar was accelerated by ethylene and postponed by 1-MCP treatment, while the Xue Ying Tao Hua cultivar was ethylene-insensitive. However, limited information is available on the effects of NAA on flower opening and petal growth in cut roses, as well as on the differences in the response to NAA treatment among cultivars. Therefore, in this study, we investigated the effects of different concentrations of NAA in flower opening and petal growth in three cut rose cultivars.

\section{Material and Methods}

Rose (Rosa sp.) cultivars Princess Meg, Red Star and Madrid were used in this study. Flowers of these rose cultivars were obtained at the commercial harvest stage (buds with petals visible through a crack in the sepal) from a commercial nursery in Aichi Prefecture, Japan. Cut flowers were transported at $4^{\circ} \mathrm{C}$ under dry condition to the laboratory within one day. Soon after arrival, the stems were cut in water to a uniform length of $30 \mathrm{~cm}$, and the stem ends of three cut flowers were immersed in $2 \%(\mathrm{w} / \mathrm{v})$ sucrose and $0.02 \%(\mathrm{w} / \mathrm{v})$ 8-hydroxyquinoline monohydrate solution (Wako Pure Chemical Industries Ltd., Japan), supplemented with or without NAA $(0,100$ or $1,000 \mu \mathrm{M})$ (Wako Pure Chemical Industries Ltd.).

Cut flowers were maintained in a plant growth chamber (BioTron; Nippon Medical \& Chemical Instruments Co., Ltd., Japan) at $25^{\circ} \mathrm{C}, 60 \%$ relative humidity, $12 \mathrm{~h}$ light $/ 12$ $\mathrm{h}$ dark photoperiod, and $20-30 \mu \mathrm{mol} \mathrm{m} \mathrm{m}^{-2} \mathrm{~s}^{-1}$ photosynthetic photon flux density.

The diameter and fresh weight (FW) of cut roses were measured once every 2 days during each experimental period. Vase life was defined as the period from the start of the treatment to petal wilting (Norikoshi et al., 2012). The condition of the flowers was visually assessed every day, at the same time of the day. Five outermost petals of the control, $100 \mu \mathrm{M}$ and 1,000 $\mu \mathrm{M}$ NAA-treated cut flowers were sampled at two, four, and six days following treatment, and the FW of the sampled petals was measured. Three flowers were used for each treatment (control, $100 \mu \mathrm{M}$ and 1,000 $\mu \mathrm{M}$ NAA treatment), and experiments were repeated three times. The data was subjected to analysis of variance, and differences across means were determined using Tukey's test, with significance defined as $p<0.05$.

\section{Results and Discussion}

NAA treatment promoted flower opening in all rose cultivars (Figure 1). Flowers treated with 1,000 $\mu \mathrm{M}$ NAA opened earlier than those untreated (control) at two days after treatment. All cut flowers treated with NAA withered within six days, and vase life was shorter than control (Table 1). Cut flowers treated with $100 \mu \mathrm{M}$ NAA showed almost the same speed in flower opening as those treated with $1,000 \mu \mathrm{M}$ NAA (data not shown).

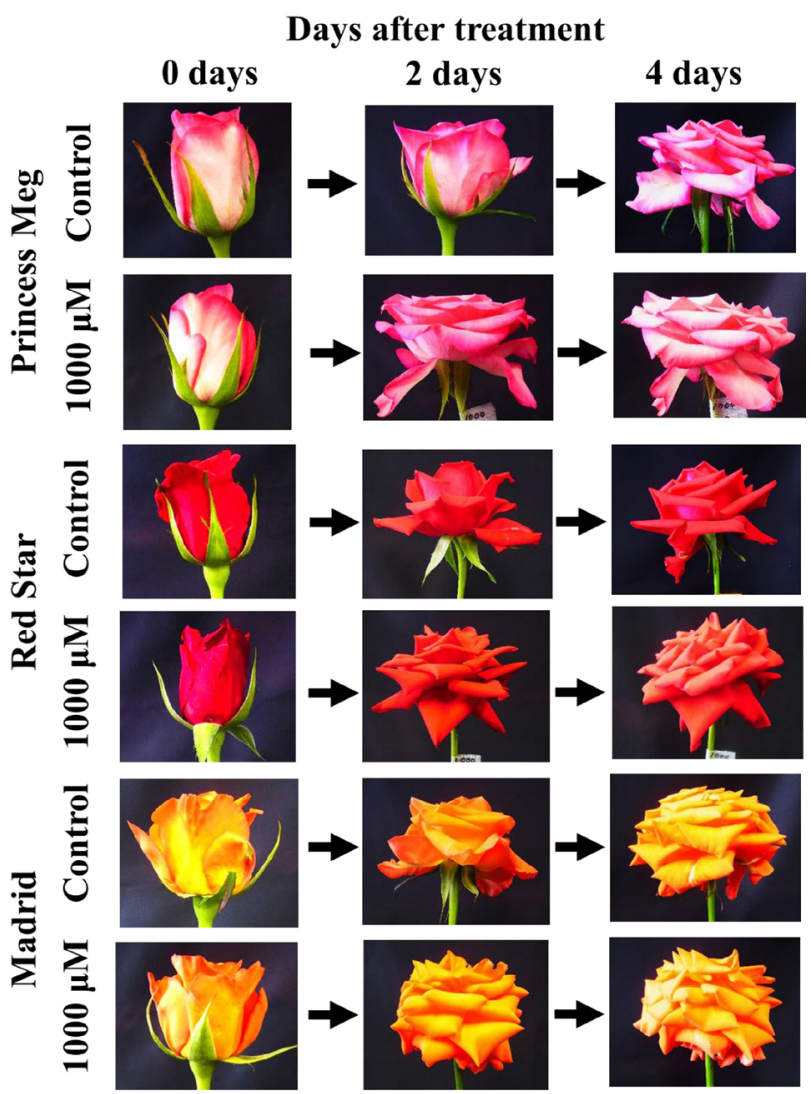

Figure 1. Pattern of flower opening and petal wilting in cut rose cultivars at 2-6 days following NAA treatment. Flowers of three rose cultivars, Red Star, Princess Meg, and Madrid, were treated with $2 \%(\mathrm{w} / \mathrm{v})$ sucrose and $0.02 \%(\mathrm{w} / \mathrm{v})$ 8-hydroxyquinoline monohydrate solution, supplemented with 0 (control) or $1,000 \mu \mathrm{M}$ NAA. 
Table 1. Vase life (days) of rose cultivars in each treatment. Three rose cultivars were used in the experiments: Princess Meg, Red Star, and Madrid. Control, 2\% (w/v) sucrose plus $0.02 \%(\mathrm{w} / \mathrm{v})$ 8-hydroxyquinoline monohydrate; 100 $\mu \mathrm{M}, 100 \mu \mathrm{M}$ NAA in addition to $2 \% \mathrm{w} / \mathrm{v}$ sucrose with $0.02 \% \mathrm{w} / \mathrm{v}$ 8-hydroxyquinoline monohydrate; $1,000 \mu \mathrm{M}$, $1,000 \mu \mathrm{M}$ NAA in addition to $2 \% \mathrm{w} / \mathrm{v}$ sucrose with $0.02 \%$ w/v 8-hydroxyquinoline monohydrate. Means followed by a different letter within same cultivar are significantly different, according to the least significant difference (Tukey's test, $p<0.05$ ). Values are means $\pm \operatorname{SE}(n=9)$.

\begin{tabular}{|l|c|c|}
\hline Cultivar & Treatment & Vase Life \\
\hline \multirow{2}{*}{ Princess Meg } & control & $5.74 \pm 0.21^{\mathrm{z}} \mathrm{a}$ \\
\hline & $100 \mu \mathrm{M}$ & $4.41 \pm 0.32 \mathrm{~b}$ \\
\hline \multirow{2}{*}{ Red Star } & $1000 \mu \mathrm{M}$ & $4.22 \pm 0.22 \mathrm{~b}$ \\
\hline & $100 \mu \mathrm{M}$ & $4.71 \pm 0.27 \mathrm{~b}$ \\
\hline \multirow{2}{*}{ Madrid } & $1000 \mu \mathrm{M}$ & $4.53 \pm 0.23 \mathrm{~b}$ \\
\hline & $100 \mu \mathrm{M}$ & $6.24 \pm 0.15 \mathrm{a}$ \\
\hline
\end{tabular}

Different letters indicate significant differences among treatments in same cultivar (Tukey's test, $\mathrm{p}<0.05$ ); ${ }^{\mathrm{z} a v e r a g e} \pm \mathrm{SE}(\mathrm{n}=9$ ).

The relative fresh weight (FW) showed changes in the whole weight of the cut flower, defining the weight of cut rose at day zero as $100 \%$. That of the control samples in all cultivars increased by about $14 \%$ from zero to six days after treatment and then decreased (Figure 1).

In all three cultivars, the relative FW of flowers treated with 1,000 $\mu \mathrm{M}$ NAA was significantly higher than that of flowers treated with 0 and $100 \mu \mathrm{M}$ NAA at 2 days posttreatment, but then decreased to levels significantly lower than that of the control at six days post-treatment (Figure 2).

In $1,000 \mu \mathrm{M}$ NAA treatment, the relative $\mathrm{FW}$ of flowers was about 40\% lower in Princess Meg, about 30\% lower in Red Star and about 35\% lower in Madrid at 6 days post-treatment, when compared to the control (Figure 2). A similar trend was observed in the $100 \mu \mathrm{M}$ NAA treatment, although no significant differences were observed in the three cultivars when compared to the control at 2 days post-treatment (Figure 2). In all cultivars, the diameter of flowers treated with $1,000 \mu \mathrm{M}$ NAA increased at two days and decreased at 6 days post-treatment, suggesting that NAA accelerates flower expansion and petal withering (Figure 3).

Compared to the control, the FW of the petals of the Princess Meg and Red Star flowers treated with 1,000 $\mu \mathrm{M}$ NAA was significantly higher at 2 days post-treatment and significantly lower at six days post-treatment (Figures 4A and 4B). In $1,000 \mu \mathrm{M}$ NAA treatment, it was about $18 \%$ higher in Princess Meg, and about 13\% higher in Red Star at 2 days post-treatment (Figures $4 \mathrm{~A}$ and 4B). However, no significant differences were observed in the FW of the petals of Madrid between the

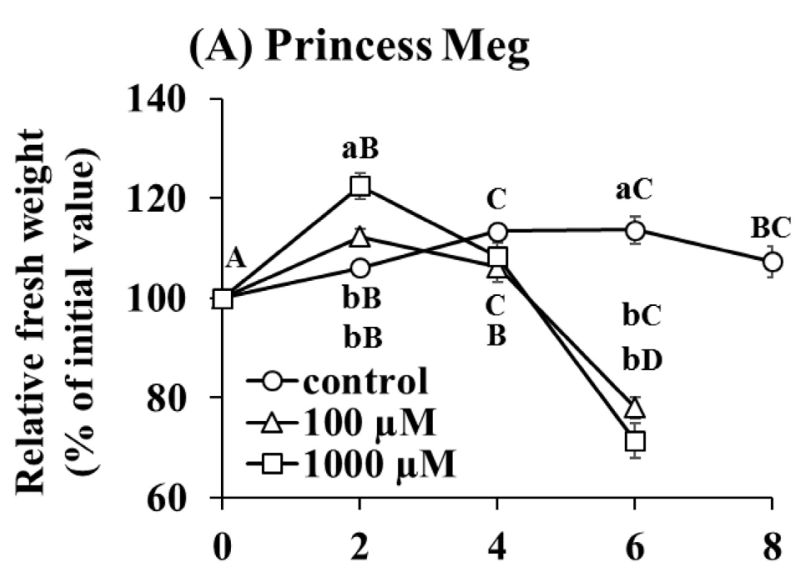

(B) Red Star

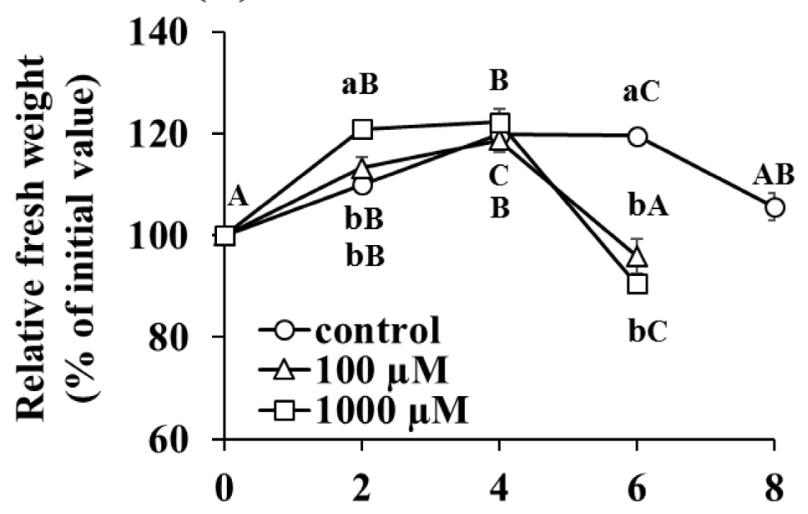

(C) Madrid

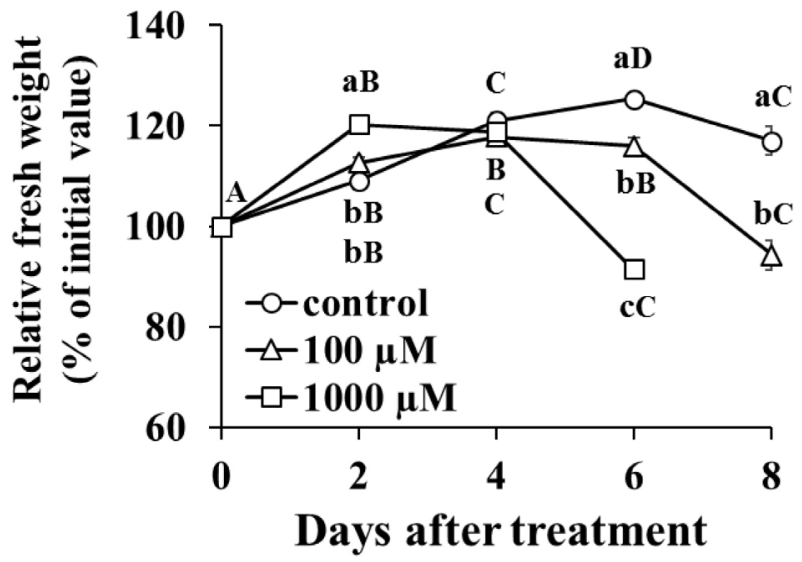

Figure 2. Relative fresh weight (FW) of cut roses treated with 0 (control), 100, and 1,000 $\mu \mathrm{M}$ NAA. (A) Princess Meg; (B) Red Star; (C) Madrid. Means followed by a different small letter within each day and capital

letter for same treatment are significantly different, according to the least significant difference (Tukey's test, $\mathrm{p}<0.05)$. Values are means $\pm \mathrm{SE}(\mathrm{n}=9)$.

control and 1,000 $\mu \mathrm{M}$ NAA treatments, except at 6 days post-treatment (Figure 4C).

Together, these results suggest that NAA treatment promotes petal growth and accelerates flower opening. However, the relative FW of cut flowers and petal FW decreases at 6 days after NAA treatment, presumably 
because flowers treated with NAA wilt earlier than those untreated.

Several studies have shown importance of sugar in flower opening and its vase life (Dung et al., 2017; Cavasini et al., 2018; Gómez-Merino et al., 2020). The accumulation of sugars in petal cells decreases the water potential, thus promoting water influx, which likely leads to cell enlargement and flower opening (Van Doorn and Kamdee, 2014). Horibe et al. (2013) reported that NAA activates the invertase enzyme, which metabolizes sucrose translocated from source to sink tissues in petals, and this activation appears to affect the translocation

\section{(A) Princess Meg}

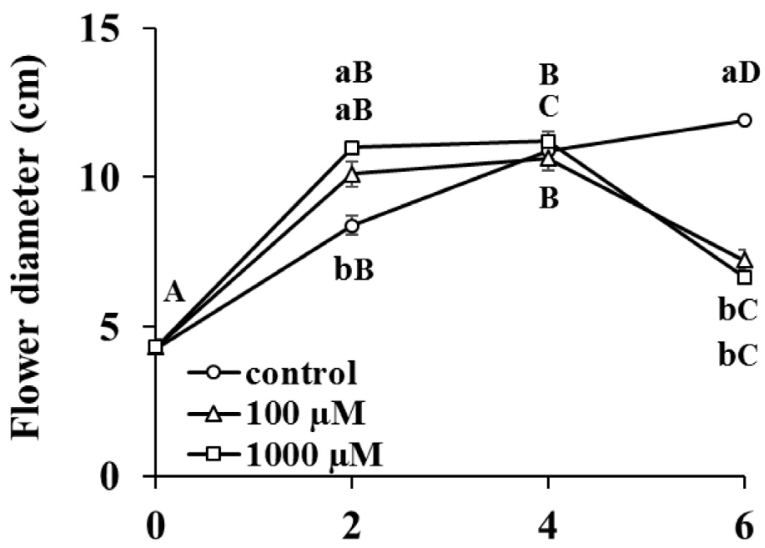

(B) Red Star

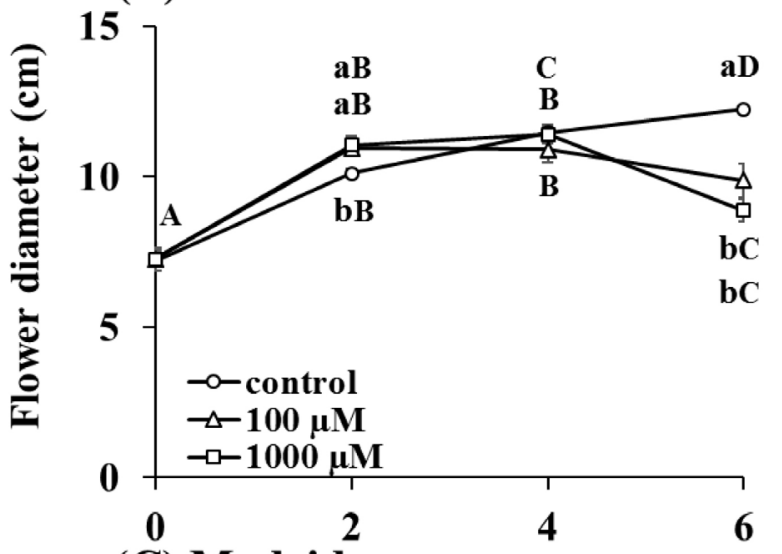

(C) Madrid

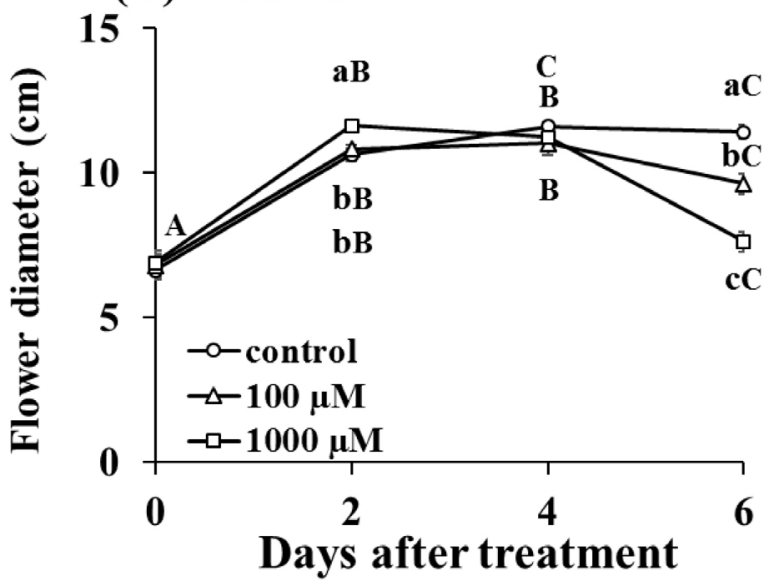

Figure 3. Flower diameter of cut roses treated with 0 (control) and 1,000 $\mu$ M NAA. (A) Princess Meg; (B) Red Star; (C) Madrid. Means followed by a different small letter within each day and capital letter for same treatment are significantly different, according to the least significant difference (Tukey's test, $\mathrm{p}<0.05$ ). Values are means $\pm \operatorname{SE}(\mathrm{n}=9)$.

\section{(A) Princess Meg}

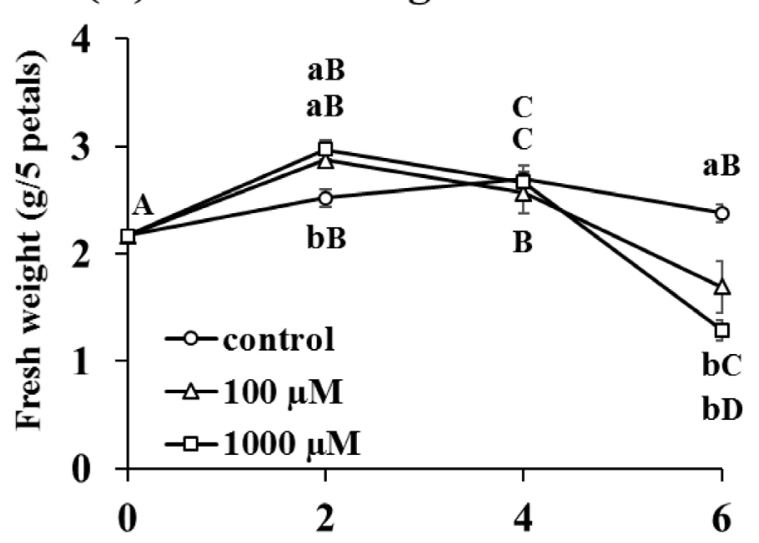

(B) Red Star

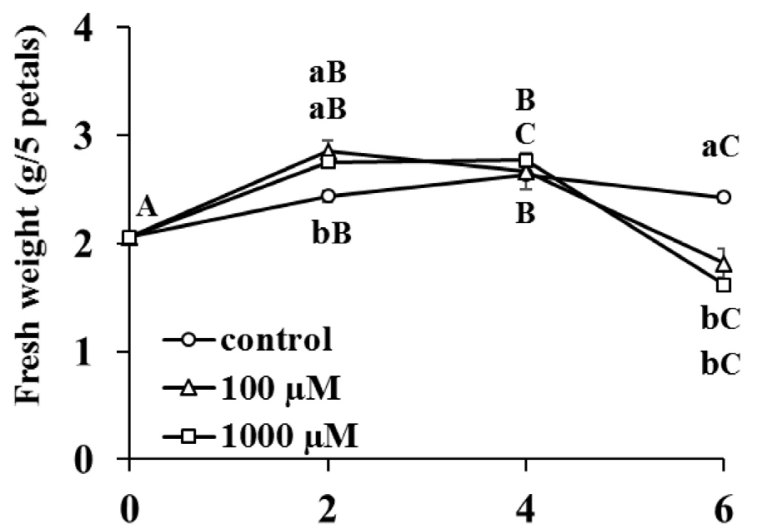

(C) Madrid

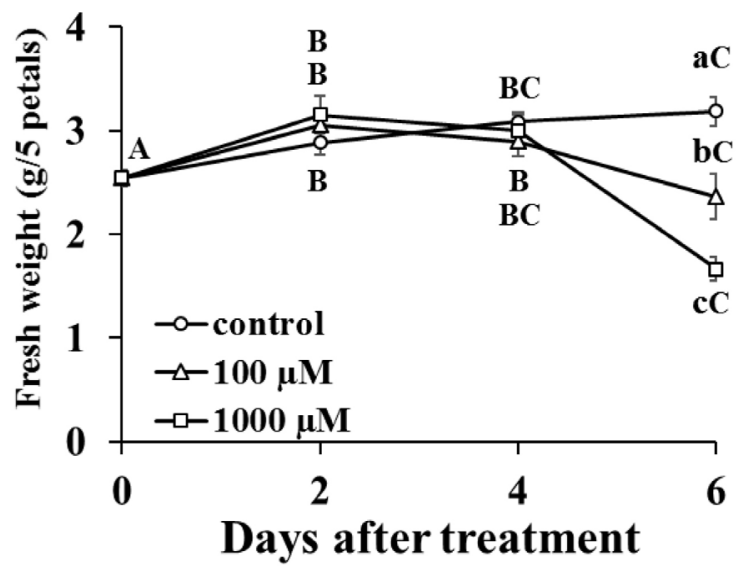

Figure 4. Petal fresh weight (FW) during flower opening in the control and $1,000 \mu \mathrm{M}$ NAA treatments. (A) Princess Meg; (B) Red Star; (C) Madrid. Means followed by a different small letter within each day and capital letter for same treatment are significantly different, according to the least significant difference (Tukey's test, $\mathrm{p}<0.05)$. Values are means $\pm \operatorname{SE}(n=9)$. 
of sucrose from leaves to petals during petal growth. Changes in sugar metabolism in petals and leaves caused by NAA treatment may play a role in promoting flower opening in cut roses. In rose cultivars with low soluble sugar content, flower opening and petal development are incomplete (Ichimura et al., 2005). Thus, exogenously applied NAA may promote full flower opening in these cultivars. NAA treatment may also be useful in other cut flower species that exhibit low rates of full bud and flower opening.

However, further studies are needed to verify the effectiveness of NAA treatment in regulating cut flower opening. Presently, the physiological mechanisms involved in the process of rose flower opening in response to NAA treatment remain unknown. The process of rose flower opening involves irreversible petal growth and reflection, in which existing cells enlarge and FW and dry weight increase (Van Doorn and Kamdee, 2014; Horibe and Yamada, 2017).

Nearly all the cells in rose petals stop dividing even when the petals are covered by the calyx (Horibe and Yamada, 2017; Ma et al., 2018), suggesting that flower opening-associated rose petal growth depends on cell expansion. The enlargement of rose petals depends on sugar accumulation in vacuoles, loosening of the cell wall, and subsequent water flow into the cells (Horibe and Yamada, 2017). The cell cannot expand when the cell wall of petals is rigid because of impeded water flow into the cell. In roses, cell wall loosening-related genes (RhEXPAI and $R h X T H 1)$ are thought to be involved in petal expansion (Horibe and Yamada, 2017).

The auxin has been shown to stimulate cell expansion and division via the promotion of cell wall flexibility and extensibility, which depends on the cell wall modification (Lehman et al., 2017; Majda and Robert, 2018). Ke et al. (2018) reported petal cell expansion at flower opening stage, while shrinkage at flower closure stage is tightly correlated with endogenous auxin in Nymphaea colorata. Using transcriptome analysis, they suggested that auxin was highly synthesized and transported to the cell wall, subsequently leading to the dramatic loosening and reorganization of cell wall during flower opening stage. While auxin synthesis was relatively delayed with low auxin flow to the cell wall during flower closure stage when cell expansion was restricted (Ke et al., 2018), they also showed that exogenous NAA treatment enhanced the rate of flower opening, while auxin transport inhibitor 2,3,5-triiodobenzoic acid (TIBA) suppressed flower opening (Ke et al., 2018).

Thus, there is a possibility that a similar mechanism exists in roses, and exogenous NAA treatment may lead to cell wall remodeling and promote petal growth, leading to faster flower opening. Further research is needed to understand the role of these proteins in the response of cut roses to NAA treatment.

\section{Conclusions}

In conclusion, we showed that 100 and 1,000 $\mu \mathrm{M}$ NAA treatment significantly accelerated flower opening, as well as petal wilting in three cut rose cultivars. It is important to develop methods to control the rate of flower opening and senescence in ornamental plants, according to the needs of consumers. Our results suggest that NAA shows high potential as an agent for accelerating flower opening in cut roses. NAA treatment may also be useful for other cut flower species that exhibit low rates of full bud and flower opening. Thus, the effect of NAA on flowering in other cultivars and species, as well as appropriate doses in cut roses, will need to be verified.

\section{Author contribution}

TH: designed and conducted the experiment, assessed results, compiled data, wrote the manuscript, and was in charge of overall direction and planning. MM: assisted in experimental and laboratory work, and provided critical feedback. All authors participated in discussion of the manuscript.

\section{References}

ABEBIE, B.; PHILOSOPH-HADAS, S.; RIOV, J.; HUBERMAN, M.; GOREN, R.; MEIR, S. Raising the $\mathrm{pH}$ of the pulsing solution improved the acropetal transport of NAA and 2,4-D and their efficacy in reducing floret bud abscission of red cestrum cut flowers. Frontiers in Plant Science, v.24, p.825, 2020. https://doi.org/10.3389/fpls.2020.00825

CAVASINI, R.; LASCHI, D.; TAVARES, A.R.; LIMA, G.P.P. Carbohydrate reserves on postharvest of lisianthus cut flowers. Ornamental Horticulture, v.24, n.1, p.12-18, 2018. https://doi.org/10.14295/oh.v24i1.1108

DUNG, C.D.; SEATON, K.; SINGH, Z. Influence of type and concentration of sugars, supplemented with 8-hydroxyquinoline sulphate, on the vase life of waxflower. Folia Horticulturae, v.29, n.1, p.39-49, 2017. https://doi. org/10.1515/fhort-2017-0005

GÓMEZ-MERINO, F.C.; RAMÍREZ-MARTÍNEZ, M.; CASTILLO-GONZÁLEZ, A.M.; TREJO-TÉLLEZ, L.I. Lanthanum prolongs vase life of cut tulip flowers by increasing water consumption and concentrations of sugars, proteins and chlorophylls. Scientific Reports, v.10, 4209, 2020. https://doi.org/10.1038/s41598-020-61200-1

HORIBE, T.; YAMADA, K. Petal growth physiology of cut rose flowers: Progress and future prospects. Journal of Horticultural Research, v.25, n.1, p.5-18, 2017. https:// doi.org/10.1515/johr-2017-0001

HORIBE, T.; YAMADA, K. Petals of cut rose flower show diurnal rhythmic growth. Journal of the Japanese Society for Horticultural Science, v.83, n.4, p.302-307, 2014. https://doi.org/10.2503/jjshs1.CH-101

HORIBE, T.; YAMAKI, S.; YAMADA, K. Effects of auxin and methyl jasmonate on cut rose petal growth through activation of acid invertase. Postharvest Biology 
and Technology, v.86, p.195-200, 2013. https://doi org/10.1016/j.postharvbio.2013.06.033

ICHIMURA, K.; KISHIMOTO, M.; NORIKOSHI, R.; KAWABATA, Y.; YAMADA, K. Soluble carbohydrates and variation in vase-life of cut rose cultivars 'Delilah' and 'Sonia'. Journal of Horticultural Science and Biotechnology, v.80, n.3, p.280-286, 2005. https://doi.org/ 10.1080/14620316.2005.11511930

KE, M.; GAO, Z.; CHEN, J.; QIU, Y.; ZHANG, L.; CHEN, $\mathrm{X}$. Auxin controls circadian flower opening and closure in the waterlily. BMC Plant Biology, v.18, 143, 2018. https:// doi.org/10.1186/s12870-018-1357-7

KHANDAKER, M.M.; RASDI, M.Z.M.D.; NAEIMAH, N.N.; MAT, N. Effects of naphthalene acetic acid (NAA) on the plant growth and sugars effects on the cut flowers Mokara Chark Kuan orchid. Bioscience Jornal, v.33, n.1, p.19-30, 2017. https://doi.org/10.14393/BJ-v33n1a2017-34908

LEHMAN, T.A.; SMERTENKO, A.; SANGUINET, K.A. Auxin, microtubules, and vesicle trafficking: conspirators behind the cell wall. Journal of Experimental Botany, v.68, n.13, p.3321-3329, 2017. https://doi.org/10.1093/jxb/erx205

MA, N.; MA, C.; LIU, Y.; SHAHID, M.O.; WANG, C.; GAO, J. Petal senescence: a hormone view. Journal of Experimental Botany, v.69, n.4, p.719-732, 2018. https:// doi.org/10.1093/jxb/ery009

MAJDA, M.; ROBERT, S. The role of auxin in cell wall expansion. International Journal of Molecular
Sciences, v.19, n.4, p.951, 2018. https://doi.org/10.3390/ ijms19040951

MINISTRY OF AGRICULTURE, FORESTRY AND FISHERIES. 2017. Available at: <https://www.maff. go.jp/j/tokei/kouhyou/nougyou_sansyutu/> Accessed on: March 2, 2020.

NORIKOSHI, M.; IMANISHI, H.; ICHIMURA, K. Effects of vase solution and air temperatures and isothizolinonic germicides on the vase life of cut rose flowers. Environmental Control in Biology, v.50, n.4, p.329-334, 2012. https://doi.org/10.2525/ecb.50.329

SHIMIZU-YUMOTO, H.; ICHIMURA, K. Combination pulse treatment of 1-naphthaleneacetic acid and aminoethoxyvinylglycine greatly improves postharvest life in cut Eustoma flowers. Postharvest Biology and Technology, v.56, n.1, p.104-107, 2010. https://doi. org/10.1016/j.postharvbio.2009.10.001

VAN DOORN, W.G.; KAMDEE, C. Flower opening and closure: an update. Journal of Experimental Botany, v.65, n.20, p.5749-5757. 2014. https://doi.org/10.1093/jxb/ eru327

WU, F.; ZHANG, C.; WANG, X.; GUO, J., DONG, L. Ethylene-influenced development of tree peony cut flowers and characterization of genes involved in ethylene biosynthesis and perception. Postharvest Biology and Technology, v.125, p.150-160, 2017. https://doi. org/10.1016/j.postharvbio.2016.11.014 